\title{
PENGARUH MEDIA VIDEO "LAPTOP SI UNYIL" TERHADAP KEMAMPUAN MENULIS TEKS \\ PROSEDUR OLEH SISWA KELAS VII \\ SMP SWASTA MARISI MEDAN \\ TAHUN PEMBELAJARAN \\ 2016/2017
}

\author{
Oleh \\ Yosefin Sari Fransenia Hutapea (yosefinsfh@yahoo.com) \\ Trisnawati Hutagalung, S.Pd., M.Pd
}

\begin{abstract}
ABSTRAK
Penelitian ini bertujuan untuk mengetahui pengaruh media video "Laptop Si Unyil" terhadap kemampuan menulis teks prosedur oleh siswa kelas VII SMP Swasta Marisi Medan Tahun Pembelajaran 2016/2017. Populasi dalam penelitian ini adalah seluruh siswa kelas VII SMP Swasta Marisi Medan Tahun Pembelajaran 2016/2017 yang berjumlah 65 siswa. Sampel penelitian ini adalah kelas VII-2 yang berjumlah 30 siswa. Metode dalam penelitian ini adalah metode eksperimen dengan design one group pre-test post-test. Dari pengolahan data diperoleh hasil pre-test dengan rata-rata $=52,83$, standar deviasi $=11,59$. Sedangkan hasil post-test dengan ratarata $=79,6$, standar deviasi $=10,40$. Dari pre-test diperoleh $\mathrm{L}_{\text {hitung }}<\mathrm{L}_{\text {tabel }}$ yaitu $0,155<0,161$ dan data post-test diperoleh $\mathrm{L}_{\text {hitung }}<\mathrm{L}_{\text {tabel }}$ yaitu $0,120<0,161$. Sedangkan dari uji homogenitas diperoleh bahwa sampel penelitian ini berasal dari populasi yang homogen yaitu $F_{\text {hitung }}<F_{\text {tabel }}$ yakni $1,24<1,84$. Selanjutnya diperoleh $\mathrm{t}_{\mathrm{o}}$ sebesar 9,56. Selanjutnya $\mathrm{t}_{\mathrm{o}}$ dikonsultasikan dengan tabel $\mathrm{t}$ dengan taraf signifikan 5\% dengan $\mathrm{dk}=29$, maka diperoleh taraf signifikan 5\% sebesar 2,04. Maka dapat diketahui bahwa $t_{\text {hitung }}>t_{\text {tabel }}$ yakni 9,56 $>2,04$. Dengan demikian, Ho ditolak dan Ha diterima. Hal ini membuktikan bahwa ada pengaruh media video "Laptop Si Unyil" terhadap kemampuan menulis teks prosedur siswa Kelas VII SMP Swasta Marisi Medan Tahun Pembelajaran 2016/2017.
\end{abstract}

Kata kunci: media video, video "Laptop Si Unyil", kemampuan menulis, teks prosedur.

\section{PENDAHULUAN}

Pendidikan di Indonesia tidak dapat terlepas dari pembelajaran bahasa. Pembelajaran bahasa Indonesia menjadi salah satu pembelajaran bahasa yang wajib dipelajari dan diajarkan. Pembelajaran bahasa Indonesia pada hakikatnya diarahkan untuk meningkatkan kemampuan berinteraksi secara efektif dalam membangun dan membina hubungan, mengungkapkan dan saling bertukar pengetahuan, keterampilan dan sikap berbahasa. Maka dari itu, proses 
pembelajaran bahasa Indonesia diharapkan dapat menjadi penghela pengetahuan dan keterampilan siswa sebagai penutur bahasa Indonesia yang komunikatif dan produktif.

Pada pembelajaran bahasa Indonesia terdapat empat keterampilan berbahasa yaitu menyimak, berbicara, membaca dan menulis. Dalam hal ini, keterampilan menulis merupakan salah satu keterampilan berbahasa paling kompleks karena siswa dituntut untuk untuk mampu menuangkan dan menyusun isi tulisannya ke dalam bahasa tulis. Pada Kurikulum 2013 menekankan pembelajaran bahasa Indonesia berbasis teks. Hal ini pula yang menjadikan keterampilan menulis menjadi prasyarat pencapaian kompetensi dalam pembelajaran bahasa Indonesia kurikulum 2013, karena teks dimaknai sebagai suatu satuan bahasa untuk mengungkapkan makna secara kontekstual.

Salah satu materi pembelajaran bahasa Indonesia dalam kurikulum 2013 di tingkat SMP kelas VII adalah materi teks prosedur. Penelitian ini difokuskan pada kemampuan siswa dalam menulis teks prosedur. Hal ini terlihat dalam silabus kurikulum 2013 pada K.D 4.6 yaitu Menyajikan data rangkaian kegiatan ke dalam bentuk teks prosedur dengan memperhatikan struktur, unsur kebahasaan, dan isi secara lisan dan tulis. Berdasarkan KD 4.6 ditunjukkan bahwa materi teks prosedur sangat penting dan diharapkan siswa kelas VII mampu menyajikan atau menulis teks prosedur sesuai dengan struktur dan ciri kaidah kebahasaannya. Namun pada kenyataannya keterampilan siswa untuk menulis teks prosedur masih rendah.

Berdasarkan hasil wawancara yang telah dilakukan penulis dengan Muhriyani, S.Pd. guru mata pelajaran Bahasa Indonesia bahwa, kemampuan menulis teks prosedur bagi sebagian besar siswa masih tergolong rendah. Terbukti dari nilai rata-rata siswa kelas VII tahun pembelajaran 2016/2017 pada materi menulis teks prosedur adalah nilai 50-60. Sedangkan nilai Kriteria Ketuntasan Minimal (KKM) pada pelajaran bahasa Indonesia di sekolah tersebut adalah 70.

Keadaan yang terlihat di lapangan menunjukkan bahwa terdapat beberapa faktor yang memicu rendahnya kemampuan menulis siswa, seperti sulitnya siswa dalam mengkomunikasikan pengetahuannya ke dalam bentuk tulisan karena pemahaman siswa hanya sebatas teori saja. Faktor lainnya disebabkan karena metode pembelajaran yang digunakan adalah metode ceramah yang sifatnya monoton. Hal itu sejalan dengan pendapat, Nurlailatul, dkk (2016) yang berpendapat dalam jurnalnya berjudul "Pembelajaran Menulis Teks Prosedur Berdasarkan Hasil Wawancara di Kelas VIII-A1 SMP Negeri 1 Singaraja” mengatakan bahwa untuk mendapatkan tulisan yang baik, guru tidak hanya berperan sebagai pengajar, tetapi juga harus kreatif dalam 
pembelajaran untuk menciptakan pembelajaran yang tidak monoton, dengan begitu siswa akan mendapatkan tulisan yang baik."

Hasil yang sama juga didapatkan oleh Purba dalam penelitiannya (2012) mengatakan, "Kemampuan siswa dalam menulis rendah hal tersebut disebabkan karena siswa hanya diajarkan untuk terampil menguasai teori menulis daripada terampil dalam menerapkannya." Pembelajaran menulis akan membosankan bila siswa hanya diajarkan secara teori tanpa mempraktekkan langsung. Keadaan itulah yang juga menyulitkan siswa dalam pembelajaran menulis teks prosedur, karena pembelajaran menulis teks prosedur membutuhkan praktik secara langsung dan siswa dituntut aktif dan kreatif.

Dalam menciptakan pembelajaran yang efektif, guru dituntut harus mampu menciptakan pembelajaran yang kreatif dan inovatif sehingga mendorong siswa untuk aktif selama proses pembelajaran berlangsung. Guru sebagai pengelola pembelajaran seharusnya berperan dalam menciptakan suasana belajar yang memungkinkan siswa dapat belajar dengan menyenangkan melalui media pembelajaran.

Menurut Sudjana dan Ahmad (2013), manfaat media pembelajaran dalam proses belajar siswa antara lain:

1. pengajaran lebih menarik perhatian siswa sehingga dapat menumbuhkan motivasi belajar,

2. bahan pengajaran akan lebih jelas maknanya sehingga dapat lebih dipahami oleh siswa, dan memungkinkan siswa menguasai tujuan pengajaran lebih baik,

3. metode mengajar akan lebih bervariasi, tidak hanya dengan komunikasi verbal melalui penuturan kata-kata oleh guru, siswa juga diajak untuk berperan aktif dalam pembelajaran sehingga meminimalisir kejenuhan saat mengikuti pembelajaran,

4. siswa lebih banyak melakukan kegiatan belajar, sebab tidak hanya mendengarkan uraian guru, tetapi juga aktivitas lain seperti mengamati, melakukan, mendemonstrasikan, dan lain-lain.

Salah satu sumber media yang dapat digunakan oleh guru adalah media video. Media video termasuk ke dalam media audiovisual yang merupakan perpaduan antara suara dan gambar yang secara bersamaan dapat didengar dan dilihat.

Daryanto (2012:5) menjabarkan kegunaan media video sebagai berikut:

1. memperjelas pesan agar tidak terlalu verbalistis,

2. mengatasi keterbatasan ruang, waktu, tenaga dan daya indera, 
3. menimbulkan gairah belajar, interaksi lebih langsung antara murid dengan sumber belajar,

4. memungkinkan anak belajar sesuai dengan bakat dan kemampuan visual, auditori, dan kinestetiknya,

5. memberi rangsangan yang sama, mempersamakan pengalaman, dan menimbulkan persepsi yang sama, dan

6. proses pembelajaran mengandung lima komponen komunikasi, yaitu guru (komunikator), bahan pembelajaran, media pembelajaran, peserta didik (komunikan), dan tujuan pembelajaran. Jadi, media pembelajaran adalah segala sesuatu yang dapat digunakan untuk menyalurkan pesan (bahan pengajaran) sehingga dapat merangsang perhatian, minat, pikiran, dan perasaan peserta didik dalam kegiatan belajar untuk mencapai tujuan pelajaran.

Media video "Laptop Si Unyil” dapat menjadi salah satu alternatif yang dapat digunakan oleh guru untuk menciptakan pembelajaran yang lebih bermakna dan nyata bagi siswa dalam pembelajaran menulis teks prosedur. Media video ini merupakan media video yang bersifat edukatif karena tidak hanya menghibur dengan tampilan-tampilan yang ditayangkan dalam video, tetapi juga dapat menambah wawasan baru kepada siswa dengan informasi yang up to date.

\section{METODE PENELITIAN}

Metode penelitian merupakan rangkaian cara dalam pelaksanaan penelitian untuk mencari kebenaran yang didasari oleh asumsi dasar dan pertanyaan terhadap suatu masalah yang dihadapi. Metode penelitian memegang peranan penting dalam sebuah penelitian. Arikunto (2006:22) menyatakan, "Metode penelitian merupakan struktur yang sangat penting karena berhasil tidaknya, ataupun tinggi rendahnya kualitas hasil penelitian sangat ditentukan oleh ketepatan dalam memilih metode penelitian."

Adapun metode yang digunakan dalam penelitian ini adalah metode eksperimen dengan bentuk one group pre-test post-test design. Hal ini sesuai dengan pendapat Sugiyono (2009: 11) yang menyatakan metode penelitian eksperimen merupakan metode penelitian yang digunakan untuk mencari pengaruh treatment (perlakuan) tertentu. Di dalam metode ini pengukuran dilakukan sebanyak dua kali yaitu sebelum eksperimen (pre-test) dan sesudah eksperimen (post- 
test). Metode ini digunakan dalam penelitian ini karena peneliti ingin mengetahui pengaruh media video "Laptop Si Unyil” terhadap kemampuan menulis teks prosedur.

Instrumen yang digunakan dalam penelitian ini adalah tes essay. Adapun teknik pengumpulan data yang dilaksanakan adalah dengan menugasi siswa menulis sebuah teks prosedur sesuai dengan struktur dan ciri-ciri kebahasaan teks prosedur, koherensi antar kalimat dan ejaan.

Data yang diperoleh selanjutnya dianalisis secara statistik dengan langkah-langkah analisis yaitu data hasil pre-test dan post-test disusun dalam bentuk tabel, menentukan nilai ratarata dan standar deviasi dari data hasil pre-test dan post-test, menghitung uji normalitas, uji homogenitas, dan uji hipotesis. Setelah t diketahui maka nilai tersebut akan dikonsultasikan dengan tabel pada taraf signifikan 5\% dengan derajat kebebasan $(\mathrm{dk})=\mathrm{n}-1$ pada taraf nyata $\alpha=$ 0,05. Dengan demikian, jika $t_{0}>t_{\text {tabel }}$ pada taraf nyata $\alpha=0,05$ maka hipotesis alternatif (Ha) diterima.

\section{HASIL PENELITIAN DAN PEMBAHASAN}

\section{Hasil Penelitian}

1. Kemampuan Menulis Teks Prosedur Sebelum Menggunakan Media Video "Laptop Si Unyil" (Pre-test)

Kemampuan menulis teks prosedur sebelum menggunakan media video "Laptop $\mathrm{Si}$ Unyil" memperoleh nilai tertinggi 80 dan nilai terendahnya adalah 40 dengan nilai rata-rata 52,83. Berikut ini rincian nilai siswa pada hasil tes menulis teks prosedur pada pre-test sebanyak 2 siswa berkategori baik, 4 siswa berkategori cukup, 7 siswa berkategori kurang, dan 17 siswa berkategori sangat kurang. Sesuai dengan gambaran kualitas nilai siswa secara umum 52,83 pada kategori sangat kurang.

\section{Kemampuan Menulis Teks Prosedur Sesudah Menggunakan Media Video "Laptop Si Unyil" (Post-test)}

Kemampuan menulis teks prosedur setelah menggunakan media video "Laptop Si Unyil" memperoleh nilai tertinggi 100 dan nilai terendahnya adalah 65 dengan nilai rata-rata 79,6. Berikut ini rincian nilai siswa pada hasil tes menulis teks prosedur pada post-test sebanyak 10 siswa berkategori sangat baik, 12 siswa berkategori baik, dan 8 siswa berkategori cukup. Sesuai dengan gambaran kualitas nilai siswa secara umum 79,6 pada kategori baik. 


\section{Pengaruh Media Video "Laptop Si Unyil" terhadap Kemampuan Menulis Teks Prosedur}

Berdasarkan uji analisis dan normalitas dari data pre-test dan post-test yang diperoleh siswa merupakan data yang berdistribusi normal. Hal ini dapat dilihat dari uji normalitas hasil

post-test di kelas kontrol, yaitu $L_{\text {hitung }}<L_{\text {tabel }}(0,155<0,161)$ dan uji normalitas hasil post-test di kelas ekpserimen yaitu $L_{\text {hitung }}<L_{\text {tabel }}(0,120<0,161)$. Dari uji homogenitas juga terbukti bahwa sampel dalam penilitian ini berasal dari populasi yang homogen, nilai homogenitas yaitu, $F_{\text {hitung }<F_{\text {tabel }}}$ yakni $1,24<1,84$.

\section{Pembahasan Hasil Penelitian}

\section{Kemampuan Menulis Teks Prosedur Sebelum Menggunakan Media Video "Laptop} Si Unyil" (Pre-test)

Berdasarkan data hasil penelitian yang telah dibahas diatas, dapat dilihat bahwa kemampuan siswa kelas VII SMP Swasta Marisi Medan sebelum menggunakan media video "Laptop Si Unyil" dalam menulis teks prosedur berada pada kategori sangat kurang, dengan ratarata 52,83. Perolehan nilai rata-rata pre-test pada setiap aspeknya yakni, nilai rata-rata aspek struktur teks prosedur sebesar 19,66, aspek ciri kebahasaan sebesar 17,66, aspek penilaian koherensi sebesar 8, dan aspek EYD sebesar 7,5.

\section{Kemampuan Menulis Teks Prosedur Sesudah Menggunakan Media Video "Laptop Si Unyil" (Post-test)}

Kemampuan siswa kelas VII SMP Swasta Marisi Medan setelah menggunakan media video "Laptop Si Unyil" dalam menulis teks prosedur berada pada kategori baik, dengan ratarata 79,6. Perolehan nilai rata-rata post-test pada setiap aspeknya yakni, nilai rata-rata aspek struktur teks prosedur sebesar 31, aspek ciri kebahasaan sebesar 30,33, aspek penilaian koherensi sebesar 9,5, dan aspek EYD sebesar 8,83.

Peningkatan nilai rata-rata ini diperoleh dikarenakan adanya penggunaan media video "Laptop Si Unyil" yang mana media ini membuat siswa lebih antusias dalam kegiatan menulis teks prosedur sehingga siswa lebih aktif dan kreatif dalam berpikir dan menuangkan idenya. Dengan menggunakan media video "Laptop Si Unyil," siswa akan merasakan pengalaman baru dalam pembelajarannya dengan ditampilkannya informasi yang up to date sehingga siswa lebih memiliki gambaran secara umum tentang menulis teks prosedur. 


\section{Pengaruh Media Video "Laptop Si Unyil" terhadap Kemampuan Menulis Teks Prosedur}

Berdasarkan paparan di atas, maka dapat disimpulkan bahwa media video "Laptop Si Unyil" memiliki pengaruh yang positif dalam meningkatkan kemampuan menulis teks prosedur siswa kelas VII SMP Swasta Marisi Medan Tahun Pembelajaran 2016/2017. Hal ini dibuktikan dengan nilai rata-rata kemampuan menulis teks prosedur setelah menggunakan media video "Laptop Si Unyil" lebih tinggi atau lebih baik dari sebelum menggunakan media video "Laptop Si Unyil".

\section{PENUTUP}

Berdasarkan hasil penelitian yang telah diuraikan pada pembahasan, maka diperoleh simpulan, kemampuan menulis teks prosedur siswa kelas VII SMP Swasta Marisi Medan Tahun Pembelajaran 2016/2017 sebelum menggunakan media video "Laptop Si Unyil” tergolong dalam kategori sangat kurang, dengan nilai rata-rata siswa 52,83.

Kemampuan menulis teks prosedur siswa kelas VII VII SMP Swasta Marisi Medan Tahun Pembelajaran 2016/2017 setelah menggunakan media video "Laptop Si Unyil" tergolong dalam kategori baik, dengan nilai rata-rata siswa 79,6.

Terdapat pengaruh yang signifikan dari hasil penggunaan media video "Laptop Si Unyil" terhadap kemampuan menulis teks prosedur siswa kelas VII SMP Swasta Marisi Medan Tahun Pembelajaran 2016/2017. Hal ini terbukti dari pengujian hipotesis, yaitu yaitu $t_{\text {hitung }}>t_{\text {tabel }}$ yakni 9,56> 2,04 pada taraf siginifikan 5\%. Dengan demikian, $\mathrm{H}_{\mathrm{o}}$ ditolak dan $\mathrm{H}_{\mathrm{a}}$ diterima.

\section{DAFTAR PUSTAKA}

Arikunto, Suharsimi. 2006. Prosedur Penelitian Suatu Pendekatan Praktik, Ed Revisi VI. Jakarta: PT. Rineka Cipta.

Daryanto. 2012. Media Pembelajaran. Bandung: Satu Nusa

Nurlailatul, Siti, dkk. 2016. Pembelajaran Menulis Teks Prosedur Berdasarkan Hasil Wawancara di Kelas VIII-Al SMP Negeri 1 Singaraja. Dalam e-Jurnal Pendidikan Bahasa 
dan Sastra Indonesia Universitas Pendidikan Ganesha Jurusan Pendidikan Bahasa dan Sastra Indonesia Vol. 5, No. 3, hal 3

Purba, Lisna. 2012. Pengaruh Model Kreatif Treffinger Terhadap Kemampuan Menulis Narasi Sugestif Oleh Siswa Kelas X SMA Negeri 1 Tanjung Morawa Tahun Pembelajaran 2011/2012. Medan: Skripsi UNIMED

Sudjana, Nana dan Ahmad Rivai. 2013. Media Pengajaran. Bandung: Sinar Baru Algesindo.

Sugiyono. 2009. Metode Penelitian Bisnis (Pendekatan Kuantitatif, Kualitatif, dan R\&D). Bandung: Alfabeta 